\title{
Chapter 16 \\ New Horizons for a Data-Driven Economy: \\ Roadmaps and Action Plans for Technology, \\ Businesses, Policy, and Society
}

Tilman Becker, Edward Curry, Anja Jentzsch, and Walter Palmetshofer

\subsection{Introduction}

A key objective of the BIG project was to define a big data roadmap that takes into consideration technical, business, policy, and society aspects. This chapter describes the integrated cross-sectorial roadmap and action plan.

The second objective of the BIG project was to set up an industrial-led initiative around intelligent information management and big data to contribute to EU competitiveness and position it in Horizon 2020. This objective was reached in collaboration with the NESSI European Technology Platform with the launch of the Big Data Value Association (BDVA).

Finally the implementation of the roadmaps required a mechanism to transform the roadmaps into real agendas supported by the necessary resources (economic investment of both public and private stakeholders). This was secured with the signature of the Big Data Value cPPP (BDVcPPP) between the BDVA and the European Commission. The cPPP was signed by Vice President Neelie Kroes, the then EU Commissioner for the Digital Agenda, and Jan Sundelin, the President of the Big Data Value Association (BDVA), on 13 October 2014 in Brussels. The BDV cPPP provides a framework that guarantees the industrial leadership,

\footnotetext{
T. Becker $(\triangle)$

German Research Centre for Artificial Intelligence (DFKI), Stuhlsatzenhausweg 3, 66123

Saarbrücken, Germany

e-mail: tilman.becker@dfki.de

E. Curry

Insight Centre for Data Analytics, National University of Ireland Galway, Lower Dangan,

Galway, Ireland

e-mail: edward.curry@insight-centre.org
}

\footnotetext{
A. Jentzsch • W. Palmetshofer

Open Knowledge Foundation (OKF), Singerstr. 109, 10179 Berlin, Germany

e-mail: anja.jentzsch@okfn.org; walter.palmetshofer@okfn.org
} 
investment, and commitment of both the private and public side to build a datadriven economy across Europe. The strategic objective of the BDVcPPP is to master the generation of value from big data and create a significant competitive advantage for European industry that will boost economic growth and jobs. The BDVA has produced a Strategic Research \& Innovation Agenda (SRIA) on Big Data Value that was initially fed by the BIG technical papers and roadmaps and was extended with the inputs of a public consultation that included hundreds of additional stakeholders representing both the supply and the demand side.

This chapter describes the technology, business, policy, and society roadmaps defined by the BIG project. It then introduces the Big Data Value Association and the Big Data Value contractual Public Private Partnership and describes the role played by the BIG project in their establishment. The BDVA and the BDV cPPP will provide the necessary framework for industrial leadership, investment, and commitment of both the private and the public side to build a data-driven economy across Europe.

\subsection{Enabling a Big Data Ecosystem}

Big data is becoming a ubiquitous practice in both the public and private worlds. It is not a standalone solution and depends on many layers like infrastructure, Internet of Things, broadband, networks and open source, among many others. Furthermore, critical are the non-technical issues including policy, skills, regulation, and business models.

Big data has to be embedded in the European business agenda. Policymakers therefore need to act in a timely manner to promote an environment that is supportive to organizations seeking to benefit from this inevitable progression and the opportunities it presents. Failure to develop a comprehensive big data ecosystem in the next few years carries the risk of losing further competitive advantage in comparison to other global regions.

The roadmaps described in this chapter outline the most urgent and challenging issues for big data in Europe. They are based on over 2 years of research and input from a wide range of stakeholders with regard to policy, business, society, and technology. The roadmaps will foster the creation of a big data ecosystem. They will enable enterprises, business (both large and small), entrepreneurs, start-ups, and society to gain from the benefits of big data in Europe. This chapter presents a summary of the roadmaps; a full description is available in Becker et al. (2014). 


\subsection{Technology Roadmap for Big Data}

In order to determine which technologies are needed at what point in time a systematic approach for predicting technology developments is needed. The sector-specific technology roadmaps developed establish such a framework by aligning user needs and associated requirements with technological advances and the related research questions. In contrast to a technology roadmap developed in the context of a single company, the approach taken here covers the development of a technology roadmap for the European market. As a consequence, it was not possible to come up with a precise timeline of technology milestones, as the speed of technology development and its adoption relies (a) on the degree to which the identified non-technical requirements will be addressed and (b) on the extent to which European organizations are willing to invest in and leverage big data.

Figure 16.1 depicts a consolidated technology roadmap for big data. For sectorspecific technology roadmaps, refer to Part II of this book and Zillner et al. (2014). For a more detailed description of the consolidated technology roadmap, see Becker et al. (2014).

\subsection{Business Roadmap for Big Data}

The role of business is critical to the adoption of big data in Europe. Businesses need to understand the potential of big data technologies and have the capability to implement appropriate strategies and technologies for commercial benefit. The big data business roadmap is presented in Table 16.1.

Attitude of Change and Entrepreneurial Spirit The majority of European companies and their leaderships need to tackle the core issue of using data to drive their organization. This requires that data-driven innovation becomes a priority at the top level of the organization, not just in the IT department. An entrepreneurial spirit is needed in the leadership team to deal with fast changes and uncertainties in the big data business world. Change, even with the possible consequence of failure, should be embraced.

Business Models In the coming years, the business environment will undergo major changes due to transformation by big data. Existing business models may change and new models will emerge. Businesses are still unclear what data analyses are of relevance and value for their business, and the return on investment is often unclear. However, they recognize the need to analyse the data they amass for competitive advantage and to create new business opportunities. The adaption to these changes will be crucial to the success of many organizations.

Privacy by Design Privacy by design can gain more trust from customers and users. Europe needs to take a leading role in incorporating privacy by design with the business operations of all its sectors. 


\section{Data Management Engineering}

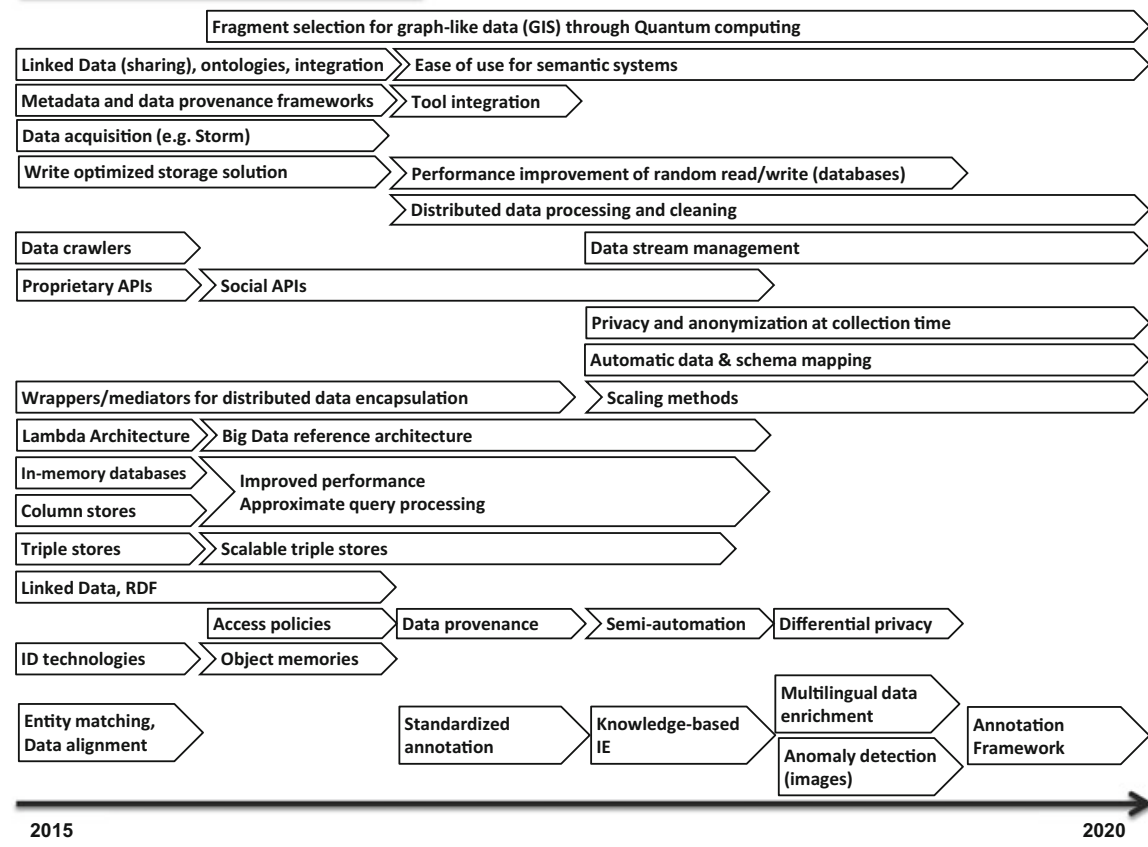

Deep Data Analytics

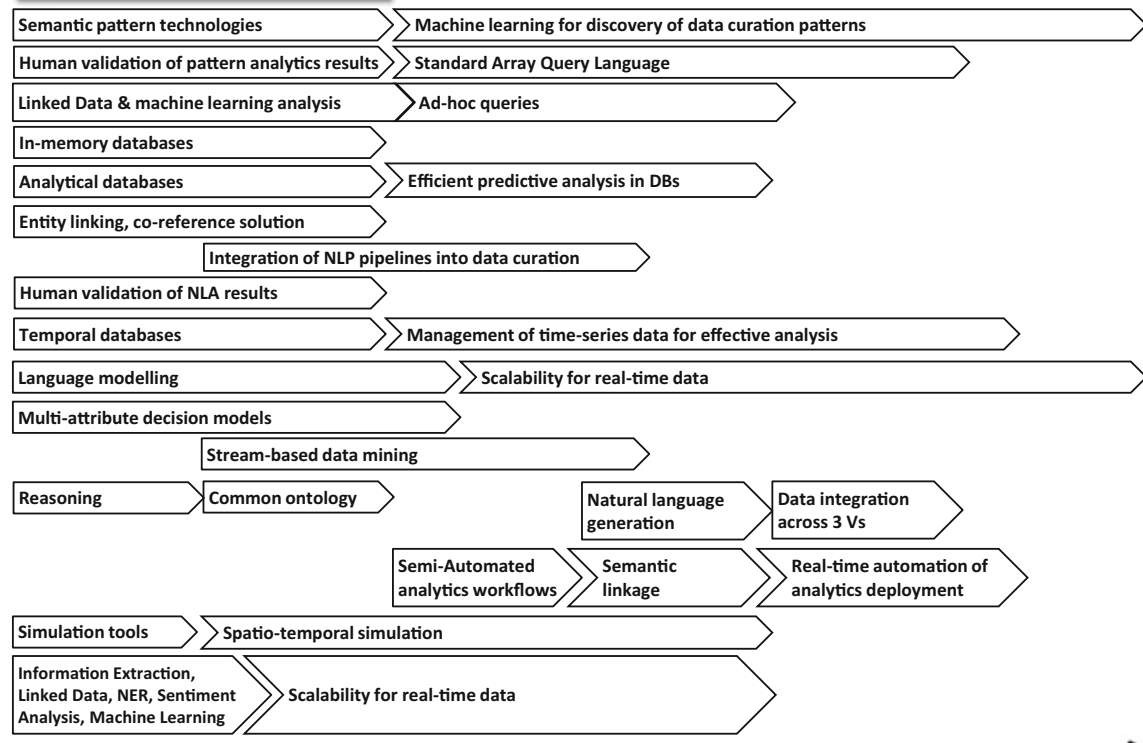

Fig. 16.1 (continued) 


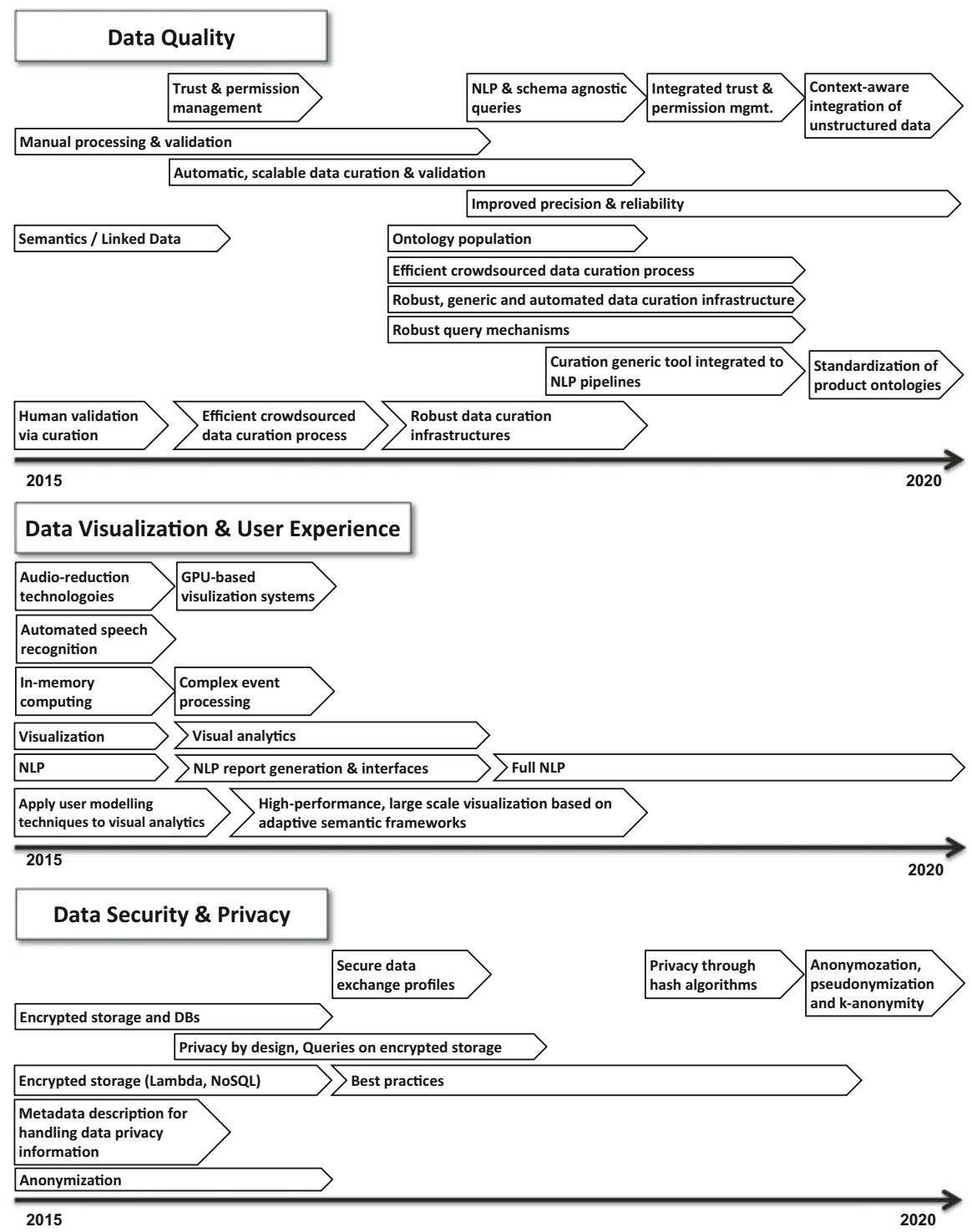

Fig. 16.1 Technology roadmap for big data

Education of Workforce There is a war for big data talent. Businesses should focus on training and educating all their staff, not just from the IT departments, with the necessary big data related skills.

Standardization Businesses need to work with other stakeholders and organizations to create the necessary technology and data standards to enable a big data ecosystem. The lack of standards, due to the non-interoperability, for example, 
Table 16.1 Business roadmap for big data

\begin{tabular}{|c|c|c|}
\hline Business & 2015 & 2019 or earlier \\
\hline $\begin{array}{l}\text { 1. Attitude of } \\
\text { change and entre- } \\
\text { preneurial spirit }\end{array}$ & $\begin{array}{l}\text { The change at top-level management } \\
\text { starts and entrepreneurial activity is } \\
\text { encouraged. }\end{array}$ & $\begin{array}{l}\text { Top-level management in } \\
\text { European businesses have a big } \\
\text { data-driven mind-set. }\end{array}$ \\
\hline 2. Business models & $\begin{array}{l}\text { Exploring business models driven by } \\
\text { big data. }\end{array}$ & $\begin{array}{l}\text { Successfully exploiting new big } \\
\text { data business models. }\end{array}$ \\
\hline $\begin{array}{l}\text { 3. Privacy by } \\
\text { design }\end{array}$ & $\begin{array}{l}\text { Start implementing privacy by } \\
\text { design. }\end{array}$ & Privacy by design by default. \\
\hline $\begin{array}{l}\text { 4. Education of } \\
\text { workforce }\end{array}$ & $\begin{array}{l}\text { New workforce educational pro- } \\
\text { grams on big data. }\end{array}$ & $\begin{array}{l}\text { Significant increase of big data } \\
\text { savvy employees in all } \\
\text { departments. }\end{array}$ \\
\hline 5. Standardization & $\begin{array}{l}\text { Identify critical standardization } \\
\text { needed. }\end{array}$ & $\begin{array}{l}\text { Major steps in standardization are } \\
\text { achieved. }\end{array}$ \\
\hline $\begin{array}{l}\text { 6. Increasing } \\
\text { research and } \\
\text { development }\end{array}$ & Increasing big data R\&D spend. & $\begin{array}{l}\text { Minimum of } 25 \% \text { increase in big } \\
\text { data R\&D spend }\end{array}$ \\
\hline
\end{tabular}

of NoSQL databases and SQL databases, is a major barrier for faster adoption of big data.

Increasing Research and Development Businesses have to focus on not losing the edge and invest in big data $R \& D$ to gain a competitive advantage for their organizations. Appropriate supports should be put in place within both the public and private sectors to foster the necessary research and innovation needed for big data value.

\subsection{Policy Roadmap for Big Data}

European policies and agendas are critical to ensuring that big data can reach its full potential in Europe. The policy roadmap for big data is available in Table 16.2.

Education and Skills Recognition and promotion of digital literacy as an important twenty-first century skill is one of the most crucial areas for the long-term success of big data in Europe. There is already a huge shortage of IT and big data professionals, and Europe is predicted to face a shortage of up to 900,000 ICT professionals by 2020. ${ }^{1}$ The skills shortage is risking the potential for growth and digital competitiveness. According to a number of studies, the demand for specific big data workers (e.g., data scientists, data engineers, architects, analysts) will further increase by up to $240 \%$ in the next 5 years $^{2}$ which could result in an additional 100,000 data-related jobs by 2020 . This problem affects not only the big

\footnotetext{
${ }^{1}$ http://europa.eu/rapid/press-release_IP-14-1129_en.htm

${ }^{2}$ http://ec.europa.eu/information_society/newsroom/cf/dae/document.cfm?doc_id=6243
} 
Table 16.2 Policy roadmap for big data

\begin{tabular}{l|l|l}
\hline Policies & 2015 & 2019 or earlier \\
\hline $\begin{array}{l}\text { 1. Education and } \\
\text { skills }\end{array}$ & $\begin{array}{l}\text { Big data education shortcom- } \\
\text { ings are tackled. }\end{array}$ & Best continent for big data education. \\
\hline $\begin{array}{l}\text { 2. Digital single } \\
\text { market }\end{array}$ & $\begin{array}{l}\text { Focus on creating a single } \\
\text { European data market. }\end{array}$ & $\begin{array}{l}\text { Single European data market for } \\
500 \text { million users established. }\end{array}$ \\
\hline $\begin{array}{l}\text { 3. Funding for big } \\
\text { data technology }\end{array}$ & $\begin{array}{l}\text { Maintain current funding } \\
\text { levels (850 Mio.). }\end{array}$ & $\begin{array}{l}\text { Double the size of venture capital } \\
\text { scene in Europe as of 2015. }\end{array}$ \\
\hline $\begin{array}{l}\text { 4. Open data and } \\
\text { data silos }\end{array}$ & $\begin{array}{l}\text { Discussion on open govern- } \\
\text { ment data by default. }\end{array}$ & $\begin{array}{l}\text { Europe leading in open data. Mini- } \\
\text { mized data silos. }\end{array}$ \\
\hline $\begin{array}{l}\text { 5. Privacy and legal } \\
\text { St Foster technical } \\
\text { infrastructure }\end{array}$ & $\begin{array}{l}\text { Starting public debate, EU } \\
\text { Data Protection signed. }\end{array}$ & $\begin{array}{l}\text { Continue fostering the IT } \\
\text { enviropriate balance for people and } \\
\text { businesses reached. }\end{array}$ \\
\hline
\end{tabular}

data domain, but also the whole digital landscape and has to be addressed in a general, broad, and urgent manner. Data and code-literacy should be integrated into standard curriculum from an early age. Specific big data skills like data engineering, data science, statistical techniques, and related disciplines should be taught in institutions of higher education. Easier access to work permits for non-Europeans should also be considered to help spur the European big data economy.

European Digital Single Market Despite the fact that the digital economy has existed for some time now, the EU's single market is still functioning best in more traditional areas like the trade of physical goods. It has so far failed to adapt to many of the challenges of the digital economy.

An established digital single market could lead the world in digital technology. Policymakers need to promote harmonization. This means combining 28 different regulatory systems, removing obstacles, tackling fragmentation, and improving technical standards and interoperability. Reaching this goal by 2019 is quite ambitious, but it is a necessary step towards a future European common data area.

Funding for Big Data Technology Create a friendlier start-up environment with increased access to funding. There is a lack of appropriate funding for research and innovation. Public supports and funding should increase. However, given the current budget constraints in Europe, alternative approaches also need to be considered (such as providing legal incentives for investment in big data, European Investment Bank, etc.).

Europe is also lacking an entrepreneurial atmosphere (i.e. venture capital spent per capita in comparison to USA or Israel). Fostering a better private financing environment for start-ups and SMEs is crucial.

Privacy and Legal Provide clear, understandable, reasonable rules regarding data privacy. When it comes to privacy rights and big data a double challenge is faced, lacking a European Digital Single Market, and the absence of unified user rights. This needs to be urgently addressed, since confidence and adoption of big data 
technology is dependent on the trust of the user. According to the latest indications EU Data Protection is expected to be signed in 2015, but a broader discussion will still be needed. Other areas that need to be considered are copyright and whether there is the right of data ownership.

No matter how quickly technology advances, it remains within the citizens' power to ensure that both innovation is encouraged and values are protected through law, policy, and the practices encouraged in the public and private sector. To that end, policymakers should set clear rules regarding data privacy so that organizations know what personal data they can store and for how long, and what data is explicitly protected by privacy regulations. Policy makers need to advance consumer and privacy laws to ensure consumers have clear, understandable, reasonable standards for how their personal information is used in the big data era.

Open Data and Data Silos Open data can create a cultural change within organizations towards data sharing and cooperation. From reducing the costs of data management to creating new business opportunities, many organizations are gaining benefits from opening up and sharing selected enterprise data. European governments need to start the discussion on openness by default. Harnessing data as a public resource to improve the delivery of public services. The sooner European governments open their data the higher the returns. Big Open Data should be the goal where possible.

Foster Technical Infrastructure Big data is not a standalone solution and depends on many layers like infrastructure, Internet of Things, broadband access for users, networks, open source, and many more. The cross-fertilization of these layers is vital to the success of big data. A technology push is needed to strengthen European technology providers to provide big data infrastructure that is competitive or leading when compared to other regions.

\subsection{Society Roadmap for Big Data}

In addition to the business and policy roadmaps presented, a roadmap for society in Europe has been defined. Without the support of the European citizen the up-take of big data technologies can be delayed and the opportunities available lost. A campaign to increase the awareness of the benefits of big data would be useful in order to motivate European citizens and society. This campaign could include the promotion of role models (especially females, and people with diverse backgrounds) and the positive long-term effects of the IT and innovation sectors. The society roadmap for big data is presented in Table 16.3.

Education and Skills Knowledge of mathematics and statistics, combined with coding and data skills is the basis for big data literacy. Improving big data literacy is important for the data-driven society. It is important that members of society develop fluency in understanding the ways in which data can be collected and 
Table 16.3 Society roadmap for big data

\begin{tabular}{l|l|l}
\hline Society & 2015 & 2019 or earlier \\
\hline $\begin{array}{l}\text { 1. Education and } \\
\text { skills }\end{array}$ & Are you already coding? & $\begin{array}{l}\text { Four times the coders and big } \\
\text { data skilled people in Europe as } \\
\text { in 2014. }\end{array}$ \\
\hline $\begin{array}{l}\text { 2. Collaborative } \\
\text { networks }\end{array}$ & Are you connected? & $\begin{array}{l}\text { Leading continent with regard } \\
\text { to a democratic big data } \\
\text { community. }\end{array}$ \\
\hline 3. Open data & Are you already engaged in open data? & $\begin{array}{l}\text { Europe is the leading open data } \\
\text { society. }\end{array}$ \\
\hline 4. Entrepreneurship & Are you a data innovator? & $\begin{array}{l}\text { Significant increase of big data } \\
\text { entrepreneurship. }\end{array}$ \\
\hline $\begin{array}{l}\text { 5. Civil } \\
\text { engagement }\end{array}$ & $\begin{array}{l}\text { Are you voting or staying in contact } \\
\text { with your Member of the European } \\
\text { Parliament (MEP)? }\end{array}$ & $\begin{array}{l}\text { Europe is the most digital and } \\
\text { political big data engaged } \\
\text { society. }\end{array}$ \\
\hline 6. Privacy and trust & $\begin{array}{l}\text { What's your stance on privacy? Do you } \\
\text { trust big data? }\end{array}$ & $\begin{array}{l}\text { Europe leading continent in } \\
\text { privacy. Significant increase of } \\
\text { trust in big data. }\end{array}$ \\
\hline
\end{tabular}

shared, how algorithms are employed, and for what purposes. It is important to ensure citizens of all ages have the ability and necessary tools to adequately protect themselves from data use and abuse. Initiatives such as "Code Week for Europe" are good exemplars for similar events in the big data domain.

Collaborative Networks All segments of society, from hacker spaces to start-ups, from SMEs to bigger businesses, from angle investors to politicians in Brussels, have to pull together to advance the big data agenda in Europe. Europe has the chance to become the continent to embrace big data through a bottom-up democratic process.

Open Data Open data is a good way to engage citizens and to illustrate the positive benefits of big data for organizational change, efficiency, and transparency (of course only with non-personal open government data). The goal should be big open data for Europe.

Entrepreneurship Current IT and big data developments impact the business world and society as a whole in a tremendous way. The opportunity to change things for the better for society needs to be taken. Affordable access to tools, data, technologies, and services are needed to foster an ecosystem of supports for both commercial and social entrepreneurs to exploit the potential of big data to create new products and services, establish start-ups, and drive new job creation.

Civil Engagement Every person in Europe can change the way Europe deals with the effects of big data by influencing the politics and policies in Brussels. Citizens need to understand that "Europe is you" and that their participation in the political life of the European community during this era of digital transition is needed. Civil 
society has to play a crucial role, which relies on every single citizen being an engaged citizen.

Privacy and Trust An urgent point for the success of big data in Europe is the need for an open discussion on the pros and cons of big data and privacy to build the trust of citizens. The different points of view that exist in European member states and their citizens need to be addressed. Trust has to be established in a European digital single data market where both consumer and civil liberties are protected. Citizens have to raise their voice; otherwise their demands will not be heard in the on-going discussions on privacy.

\subsection{European Big Data Roadmap}

The final step was to create an integrated roadmap that takes into consideration technical, business, policy, and society aspects. The resulting European big data roadmap is a consensus reflecting roadmap with defined priorities and actions needed for big data in Europe. The roadmap (as illustrated Fig. 16.2) is the result of over 2 years of extensive analysis and engagement with stakeholders in the big data ecosystem. It is important to note that while actions are visualized sequentially, in reality many can and should be tackled at the same time in parallel, as detailed in specific roadmaps.

\section{European Big Data Roadmap}

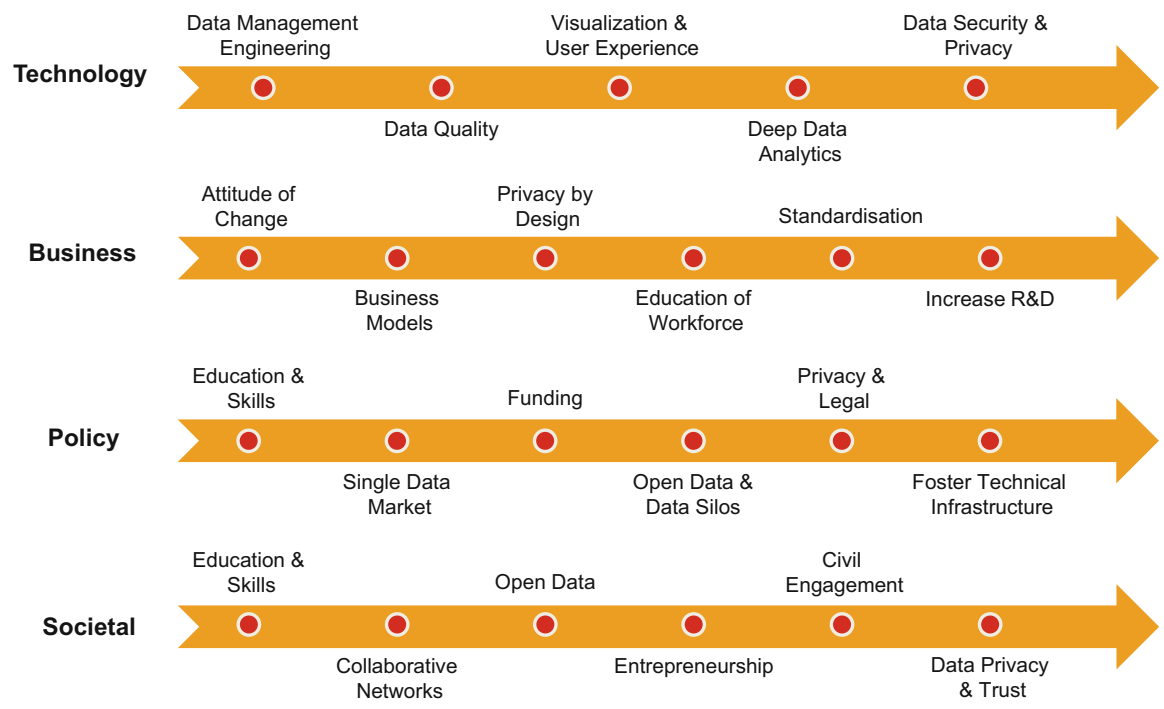

Fig. 16.2 European big data roadmap 


\subsection{Towards a Data-Driven Economy for Europe}

In her many speeches as European Digital Commissioner, Neelie Kroes called for action from European stakeholders to mobilize across society, industry, academia, and research to enable a European big data economy. VP Kroes identified it was necessary to establish and support a framework to ensure there are enough highskilled data workers (analysts, programmers, engineers, scientists, journalists, politicians, etc.) to be able to deliver the future technologies, products, and services needed for big data value chains and to ensure a sustainable stakeholder community in the future.

A key aim of the BIG project was to create new and enhance existing connections in the current European-wide big data ecosystem, by fostering the creation of new partnerships that cross sectors and domains. Europe needs to establish strong players in order to make the entire big data value ecosystem, and consequently Europe's economy, strong, vibrant, and valuable. BIG recognized the need to create venues that enable the interconnection and interplay of big data ideas and capabilities that would support the long-term sustainability, access, and development of a big data community platform. The linking of stakeholders would form the basis for a big data-driven ecosystem as a source for new business opportunities and innovation. The cross-fertilization of stakeholders is a key element for advancing the sustainable big data economy.

\subsection{Big Data Value Association}

The Big Data Public Private Forum, as it was initially called, was intended to create the path towards implementation of the roadmaps. The path required two major elements: (1) a mechanism to transform the roadmaps into real agendas supported by the necessary resources (economic investment of both public and private stakeholders) and (2) a community committed to making the investment and collaborating towards the implementation of the agendas.

The BIG consortium was convinced that achieving this outcome would require creating a broad awareness and commitment outside of the project. BIG took the necessary steps to contact major players and to liaise with the NESSI European Technology Platform to jointly work towards this endeavour. The collaboration was set up in the summer of 2013 and allowed the BIG partners to establish the necessary high-level connections at both industrial and political levels. The objective was reached in collaboration with NESSI with the launch of the Big Data Value Association (BDVA) and the Big Data Value contractual Public Private Partnership (BDV cPPP) within Horizon 2020.

The BDVA is a fully self-financed not-for-profit organization under Belgian law with 24 founding members from large and small industry and research, including many partners of the BIG project. The BDVA is an industrially led representative 
community of stakeholders ready to commit to a big data value cPPP with a willingness to invest money and time.

The objective of the BDVA is to boost European big data value research, development, and innovation. It aims to:

- Strengthen competitiveness and ensure industrial leadership of providers and end users of big data value technology-based systems and services

- Promote the widest and most effective uptake of big data value technologies and services for professional and private use

- Establish scientific excellence as the base for the creation of value from big data

The BDVA will carry out a number of activities to achieve its objectives, these include:

- Developing strategic goals for European big data value research and innovation, and supporting their implementation

- Improving the industrial competitiveness of Europe through innovative big data value technologies, applications, services, and solutions

- Strengthening networking activities of the European big data value community

- Promoting European big data value offerings and organizations

- Reaching out to new and existing users

- Contributing to policy development, education, and the ramification of technology in ethical, legal, and societal areas

\subsection{Big Data Value Public Private Partnership}

The BDVA developed a Strategic Research \& Innovation Agenda (SRIA) on Big Data Value (BDVA 2015) that was initially fed by the BIG technical papers and roadmaps and extended with the inputs of a public consultation that included hundreds of additional stakeholders representing both the supply and the demand side. The BDVA then developed a cPPP (contractual PPP) proposal as the formal step to set up a PPP on big data value. The cPPP proposal builds on the SRIA by adding additional content elements such as potential instruments that could be used for the implementation of the agenda.

A vital role in the European big data landscape will be fulfilled by the Big Data Value contractual Public Private Partnership (BDV cPPP). On 13 October 2014 the signature of BDV cPPP took place in Brussels, by the then European Commission Vice-President Neelie Kroes and the President of the BDVA Jan Sundelin, TIE Kinetix. The BDVA is the industry-led contractual counterpart to the European Commission for the implementation of the BDV cPPP. The main role of the BDVA will be to regularly update the Big Data Value SRIA, define and monitor the metrics of the BDV cPPP, and participate with the European Commission in the BDV cPPP partnership board. 
The signature of the BDV cPPP is the first step towards building a thriving data community in the EU. The BDV cPPP is driven by the conviction that research and innovation focusing on a combination of business and usage needs is the best longterm strategy to deliver value from big data and create jobs and prosperity. The strategic objectives of the BDV cPPP as stated in the BDV SRIA (BDVA 2015) are:

- Data: To access, compose, and use data in a simple, clearly defined manner that allows the transformation of data into information.

- Skills: To contribute to the conditions for skills development in industry and academia.

- Legal and Policy: To contribute to policy processes for finding favourable European regulatory environments, and address the concerns of privacy and citizen inclusion.

- Technology: To foster European BDV technology leadership for job creation and prosperity by creating a European-wide technology and application base and building up competence. In addition, enable research and innovation, including the support of interoperability and standardization, for the future basis of BDV creation in Europe.

- Application: To reinforce the European industrial leadership and capability to successfully compete on a global-level in the data value solution market by advancing applications transformed into new opportunities for business.

- Business: To facilitate the acceleration of business ecosystems and appropriate business models with particular focus on SMEs, enforced by Europe-wide benchmarking of usage, efficiency, and benefits.

- Social: To provide successful solutions for the major societal challenges that Europe is facing such as health, energy, transport, and the environment. And to increase awareness about BDV benefits for businesses and the public sector, while engaging citizens as prosumers to accelerate acceptance and take-up.

Given the broad range of objectives around focusing on the different aspects of big data value a comprehensive implementation strategy is needed. The BDVA SRIA (BDVA 2015) details an interdisciplinary implementation approach that integrates expertise from the different fields necessary to tackle both the strategic and specific objectives of the BDV cPPP. The strategy contains a number of different types of mechanisms, including cross-organizational and cross-sectorial environments known as i-Spaces, as illustrated in Fig. 16.3, which will allow challenges to be tackled in an interdisciplinary manner while also serving as hubs for research and innovation activities, lighthouse projects which will raise awareness of the opportunities offered by big data and the value of data-driven applications for different sectors, technical projects which will address targeted aspects of the technical priorities, and projects to foster and support efficient cooperation and coordination across all BDV cPPP activities. 


\section{i-Spaces}

European Innovation Spaces for providing secure places for data, building skills, identifying best practices and maturing

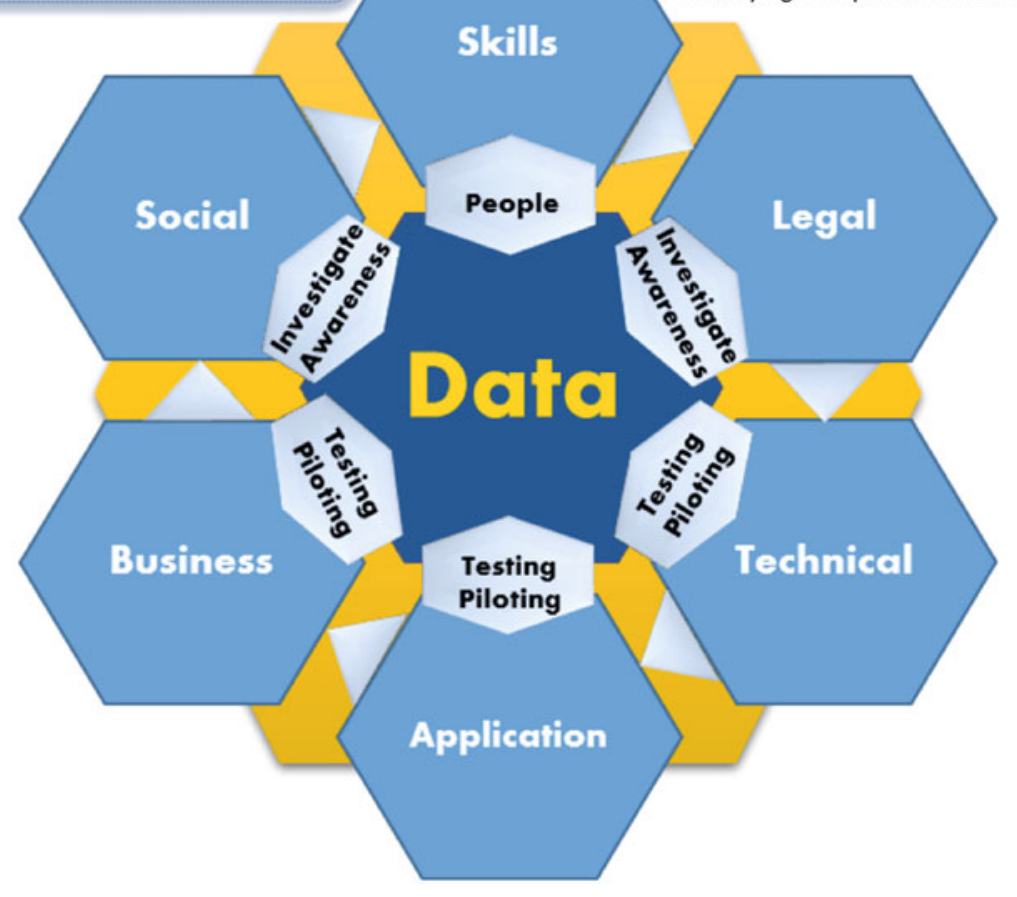

tools

Fig. 16.3 Interconnected challenges of the BDV cPPP within i-Spaces [from BDVA (2015)]

\subsection{Conclusions}

A key objective of the BIG project was to define a European big data roadmap that takes into consideration technical, business, policy, and society aspects. This chapter details the resulting cross-sectorial roadmap and associated action plans.

The second objective of the BIG project was to set up an industrial-led initiative around intelligent information management and big data to contribute to EU competitiveness and position it in Horizon 2020. The Big Data Public Private Forum, as it was initially called, was intended to create the path towards implementation of the roadmaps. The path required two major elements: (1) a mechanism to transform the roadmaps into real agendas supported by the necessary resources (economic investment of both public and private stakeholders) and (2) a community committed to making the investment and collaborating towards the implementation of the agendas. This objective was reached in collaboration with the NESSI technology platform with the launch of the Big Data Value Association (BDVA) and the Big Data Value contractual Public Private Partnership (BDV cPPP) within 
Horizon 2020. The BDVA and the BDV cPPP provide the necessary framework that guarantees the industrial leadership, investment, and commitment of both the private and the public side to build a data-driven economy across Europe. The strategic objective of the BDV cPPP is to master the generation of value from big data and create a significant competitive advantage for European industry that will boost economic growth and jobs.

Open Access This chapter is distributed under the terms of the Creative Commons AttributionNoncommercial 2.5 License (http://creativecommons.org/licenses/by-nc/2.5/) which permits any noncommercial use, distribution, and reproduction in any medium, provided the original author(s) and source are credited.

The images or other third party material in this book are included in the work's Creative Commons license, unless indicated otherwise in the credit line; if such material is not included in the work's Creative Commons license and the respective action is not permitted by statutory regulation, users will need to obtain permission from the license holder to duplicate, adapt, or reproduce the material.

\section{References}

BDVA. (2015). N. de Lama, J. Marguerite, K. D. Platte, J. Urban, S. Zillner, E. Curry (eds) European Big Data Value strategic research and innovation agenda. Big Data Value Association.

Becker, T., Jentzsch, A., Palmetshofer, W. (2014). D2.5 Cross-sectorial roadmap consolidation. Public deliverable of the EU-project BIG (318062; ICT-2011.4.4).

Zillner, S., Bretschneider, C., Oberkampf, H., Neurerer, S., Munné, R., Lippell, H. et al. (2014). D2.4.2 Final version of sectors roadmap. Public deliverable of the EU-project BIG (318062; ICT-2011.4.4). 